\title{
First report of brown rot caused by Rhizopus arrhizus on tomato in Pakistan
}

\author{
Fiza Liaquat ${ }^{1}$ - Qunlu Liu ${ }^{2}$ - Samiah Arif ${ }^{1}$ - Iftikhar Hussain Shah ${ }^{1} \cdot$ Hassan Javed Chaudhary ${ }^{1}$. \\ Muhammad Farooq Hussain Munis ${ }^{1,3}$ (ID
}

Received: 27 August 2018 / Accepted: 2 May 2019/Published online: 14 May 2019

(C) Società Italiana di Patologia Vegetale (S.I.Pa.V.) 2019

In a field survey of tomato (Solanum lycopersicum L.) in Islamabad, Pakistan, a severe fruit rot ( $72 \%$ incidence) with symptoms of brown spots was observed in 12 randomly selected fields. Symptomatic fruits were superficially disinfected and infected tissues $(2-3 \mathrm{~mm})$ were placed on Sabouraud Dextrose Agar (SDA) at $25{ }^{\circ} \mathrm{C}$. After 6 to 7 days, whitish and later grayish black mycelia with a net like structure were observed. Microscopic observations revealed various sub-globose or oval sporangiospores of 5-8 $\mu \mathrm{m}$ diameter. Straight and nonseptate sporangiophores of 1-2.1 mm length were observed. Chlamydospores were not observed. Globose sporangia of $150-210 \mu \mathrm{m}$ diameter were observed. Initially the sporangia were white and then turned black with a distinct collar. Columellae were sub-globose, pale brown, and mostly 70-100 $\mu \mathrm{m}$. These morphological characteristics were similar to those of Rhizopus arrhizus A. Fisch (syn. Rhizopus oryzae Went \& Prins. Geerl.) (Zheng et al. 2007). To confirm the morphological identification, the Internal Transcribed Spacer (ITS) region of DNA was amplified and sequenced by using the primer pair ITS1-ITS4 (White et al. 1990). Resultant sequence was deposited in NCBI database (MK445256). The resultant sequence showed $100 \%$ similarity with $R$. oryzae (syn. R. arrhizus) (KM225290.1). A pathogenicity test

Muhammad Farooq Hussain Munis munis@qau.edu.pk

1 Department of Plant Sciences, Quaid-i-Azam University, Islamabad 45320, Pakistan

2 Department of Landscape Architecture, School of Design, Shanghai Jiao Tong University, Shanghai, People's Republic of China

3 Department of Plant Pathology, University of California, Davis, CA, USA was performed following Koch's postulates. Mycelial plugs (5-mm diameter) were placed on wounded tomato fruits at $25-28{ }^{\circ} \mathrm{C}$ for one week. All inoculated fruits developed typical brown spots after 5-6 days. No symptoms were observed on wounded but non-inoculated tomato fruits. The pathogen was re-isolated from symptomatic tissues and found similar to the inoculated one. A reference isolate of fungus was deposited in a culture collection of Molecular Plant Pathology Laboratory, Department of Plant Sciences, Quaid-i-Azam University, Islamabad, Pakistan as isolate R-2 with accession no. 212.

Although $R$. arrhizus has been reported on other crops (Farr and Rossman 2018), to our knowledge this is the first report of tomato brown rot caused by this pathogen in Pakistan and worldwide.

\section{References}

Farr D.F., Rossman, A.Y., 2018. Fungal Databases, U.S. National Fungus Collections, ARS, USDA. Retrieved February 11, 2019

White TJ, Burns T, Lee S, Taylor J (1990) Amplification and direct sequencing of fungal ribosomal RNA genes for phylogenetics. In: Innis MA, Gelfand DH, Sninsky JJ, White TJ (eds) PCR protocols: a guide to methods and applications. Academic Press, San Diego, pp 315-322

Zheng RY, Chen GQ, Huang H, Liu XY (2007) A monograph of Rhizopus. Sydowia 59:273-372

Publisher's note Springer Nature remains neutral with regard to jurisdictional claims in published maps and institutional affiliations. 